\title{
Green Classrooms Towards Improved Student Behaviour Through Planting Design
}

\section{Dr. Abdullah Nidal Addas}

King Abdulaziz University

aaddas@kau.edu.sa

\begin{abstract}
There is a significant impact of classroom environments on the learning abilities of students. It has gained significant importance in the design and architecture professions. This study investigates the impact of green classrooms on the productivity and behavior of students. Twenty-two first-year students (between 19 - 22 years of age) from the landscape architecture department participated in this investigation. Participants' blood pressure and pulse rate were evaluated before and after rearranging and designing the studio (classroom) when the studio was changed into a green classroom. There was a significant improvement in the systolic pressure of students as they started studying in green classrooms (sig. $=0.017$ ). These results suggested that there is a positive impact on the productivity and behavior of students working in green classrooms, which is an indication of the need to rethink the design layout of the classrooms and study spaces.
\end{abstract}

Keywords: Behaviour, Environmental Design, Green classrooms, Plants, Student

مستخلص البحث

هنالك تأثير كبير لبيئة الفصول الدر اسية على قدر ات التعلم لدى الطلاب سواءً في المدارس أو الجامعات وقد اكتسب هذا التأثثير أهمية

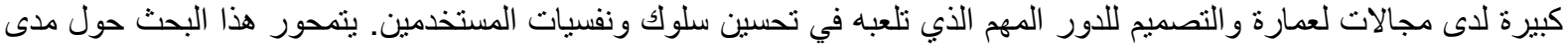

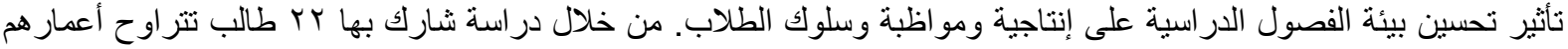

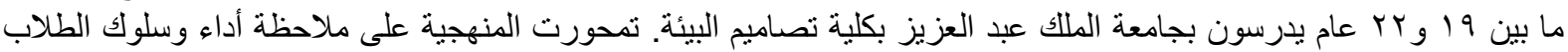
لمدة ع ا أسبوع (فصل در اسي كامل) في أحد الفصول الدراسية من ثم تم إعادة تصميم الفصل الدراسي وملاحظة سلوك الطلاب لمدة ع ا أسبوع. شملت الملاحظة أخذ قراءات للضغط ونبضات القلب للطلاب المشاركين في البحث. لوحظ انه أه بعد تغيير تصميم

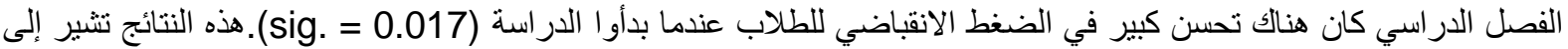
أن هناك تأثير إيجابي على إنتاجية وسلوك الطلاب الذين يعملون في الفصول الدراسية الخضر اء أو أو المصممة بعناية ، وهو ما يدل على الحاجة إلى إعادة التفكير في تصميم الفصول الدئ اسية لإنتاجية أكبر و تحسين بيئة الدر اسة لدى الطلاب.

\section{INTRODUCTION}

Classroom environments are considered to have a significant impact on students' learning. Knowledge is associated with multiple life practices, which suggested that humans possess complex and unique minds. Environmental psychologists argued that the elements of individuals' surroundings greatly influence their behaviour. The use of green classrooms has been widely studied in the fields of architecture and design, which have proposed interior design concept features that include lighting, form, texture, space, and structure (Yacan, 2014). However, in the context of classroom design, lighting is an important element of green classrooms that has been examined in depth. Therefore, green classrooms should create comfortable and peaceful environments, and contribute positively to students' psychological and physical needs. 
According to Yacan (2014), findings of studies in the field of environmental psychology suggested that the surroundings of learning environments have a significant impact on students' learning. It has contributed towards investigating the concept of green classrooms and their adoption by design and architecture academics. Positive interaction between teachers and students forms an important element of well-organised classrooms, and reduces possible incidents of challenging behaviours from students. Behaviours of inattention are observed less often among students studying in green classrooms and playing in large integrated outdoor areas containing large areas of trees and shrubbery (Martensson et al., 2009).

The construction of green classrooms varies from building to building, as it depends on orientation of each building, climate, site, and latitude. An ineffective environment within the classroom adversely affects the pattern of cortisol (hormone), which can develop stress among students and negatively affect their health and concentration. It has been observed that behaviour and circadian hormone levels of students remain effective when studying in green classrooms, because the built-in environment plays a significant role in daily activities of humans. Both teachers and students appear to recognise the value of these green classrooms (Kuller and Lindstenm 1992).

There are many studies that highlighted the benefits of softscape around the school environment (Bagot, Allen, \& Toukhsati, 2015; van den Berg \& van den Berg, 2011). Green classrooms make significant contributions towards sustainable learning activities of students due to specific building structures and daily teaching practices. The design of these classrooms helps to enrich environment, which results in enhanced test scores of students and more efficient performance by the teachers. These healthy spaces also provide clean air for students enriched with oxygen, which provides a positive impact on the health of students. However, many schools in developing countries are built in traditional styles, and often have no facilities for sustainable designs. A study conducted by Pulay (2010) suggested that classroom design has a direct and significant impact on the performance of students, because this positively affects the achievements of students in different activities and participations. Another study reported that green classrooms have a significant impact on circadian rhythms, which affect the productivity and health of students (Demir \& Konan, 2013).

Natural ventilation is a significant benefit of using green classrooms, as well as various bodily systems that are regulated by biological stimulation. Therefore, sustainable design is recognised as an important factor adopted for green classrooms, as this appears to have a strong influence on enhancing students' attainment levels. The orientation of buildings has been highlighted as another important factor, and especially negative when the effects of green plants have not been considered when building classrooms. Therefore, the orientation of classrooms needs to provide levels of natural daylight that are appropriate and sufficient. Studies of behaviour and learning attitudes of very young children indicate 
that these are strongly affected by the physical classroom environment (Tanner, 2009). A study conducted by Wang and Boubekri (2010) revealed that physical environments not only affect the behaviour of students during learning activities, but also influences their motivation to attend school. Therefore, students are more likely to be motivated to attend class lessons and learn effectively if classroom environments are attractive and encourage learning.

The environmental design of classrooms is directly associated with the social, cognitive, emotional development of students, and psychosocial interaction, such as opportunities for communication with peers, teachers, and parents. There are many factors that affect the learning opportunities for students, such as noise, sleeplessness, and classroom design; however, students' learning could be enhanced by improving the architectural design of classrooms (Yacan, 2014). Another study argued that the performance of students is positively influenced by green classrooms, and reported that students' test scores improve by up to $20 \%$ when exposed to this type of learning environment (Heschong et al., 2002). It has been indicated that students gain social, environmental, and economic benefits from learning in green classrooms, when sustainable school classrooms and traditional school classroom are compared. The benefits for students learning in green classrooms include enhancing their aesthetic qualities, improving their test scores, and enhancing their health. In addition, effective daily teaching practices and a positive classroom learning environment provide sustainable opportunities for students to learn effectively in green classrooms. These classrooms are effective, because they provide clean air to breathe and natural lighting for vision, and create learning spaces for students that are also healthy. When students are exposed to learning activities in classrooms that have facilities and designs that are traditional, they lack the benefits offered to them by green classrooms. Therefore, this study has investigated the positive effects of green classroom environments on the behaviour of students.

It is believed that the presence of plants in classrooms changes the productivity and mood of students. Therefore, this study has investigated the impact of green classrooms (plants) on behaviour and productivity of the students.

1. How are students affected by plants in the classroom?

2. How are green classrooms and an appropriate learning environment correlated?

3. What are the important elements required for providing green classrooms for students?

4. How do green classrooms integrate with the overall development of students?

\section{METHODOLOGY}

\subsection{Study Location}

The study took place at King Abdulaziz University, Faculty of Environmental design in the Landscape Architecture Department in Jeddah, Saudi Arabia. The first year students in the design studio were taught in a normal design studio (Figure 1). The student behaviour in the 
classroom was observed and their commitment to attend the lecture on time and the absence percentage were recorded during the first 14 weeks (first academic semester 2017).

Figure (1) the first year studio (The classroom in which the experiment was conducted)

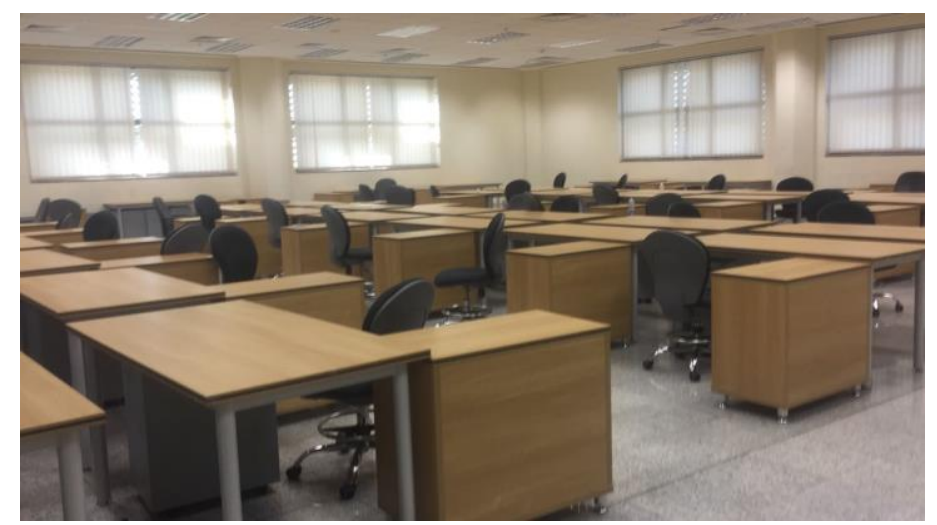

The classroom located in the third floor of the faculty building and it was furnished with drafting tables, chairs and personal lockers for the students (figure 2). The south east and north east elevations of the studio are large windows which as shown in figure 1 . These large windows offer sufficient natural light in the studio.

Figure (2) the first year studio layout plan (The classroom in which the experiment was conducted)

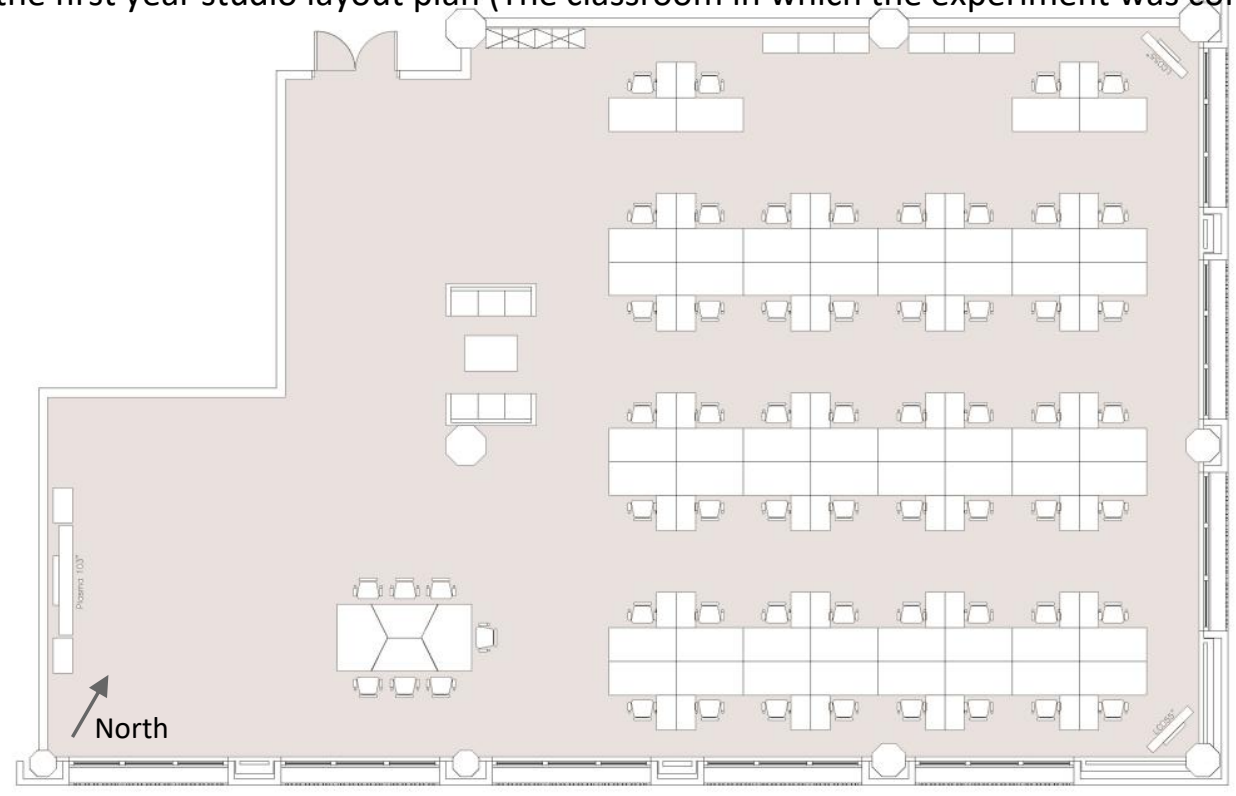

However, the views from these windows are difficulties because of the large GRC blocks (figure 3 ) that cover the windows from outside to limit the visual accessibility to the girls section. In addition, the views from the windows is overlooking to a few constructions sites and a main road in the University. 
Figure (3) The GRC block from outside and inside the studio
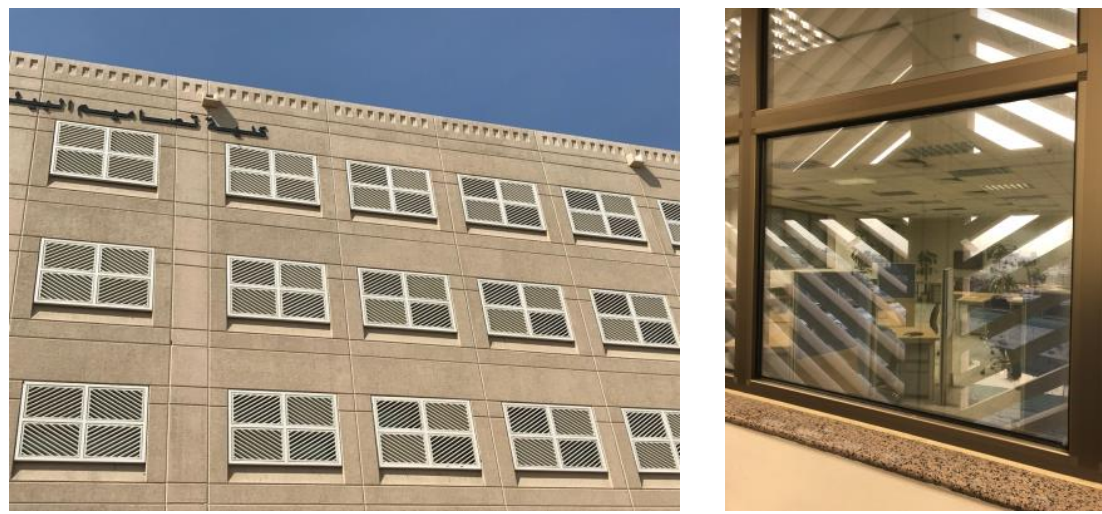

\subsection{Classroom Improvement}

By the beginning of the second term, the layout of the studio was changed, after gaining approval from the dean faculty and the department head. The researcher applied all changes at his expense. The changes that occur in the studio included bringing different types of carefully selected indoor plants (Table 1), rearranging the studio furniture (figure 4 $\& 5)$ and repaints the walls.

Table (1) indoor plants used in the study

\begin{tabular}{|l|c|c|}
\hline \multicolumn{1}{|c|}{ Plants name } & Height & Quantity \\
\hline Dracaena fragrans "Limon lime" & $1.5 \mathrm{~m}$ & 9 pots \\
\hline Dracaena fragrans "Limon lime" & $0.8 \mathrm{~m}$ & 6 pots \\
\hline Ficus benjamina L. " winter green braided" & $1.8 \mathrm{~m}$ & 2 pots \\
\hline Ficus benjamina L. " Hawaii" & $1.2 \mathrm{~m}$ & 2 pots \\
\hline Dracaena fragrans "Ker Gawl" & $1.2 \mathrm{~m}$ & 3 pots \\
\hline Dracaena deremensis Engl. & $1.2 \mathrm{~m}$ & 3 pots \\
\hline
\end{tabular}

Figure (4) the first year studio layout plan after improvements

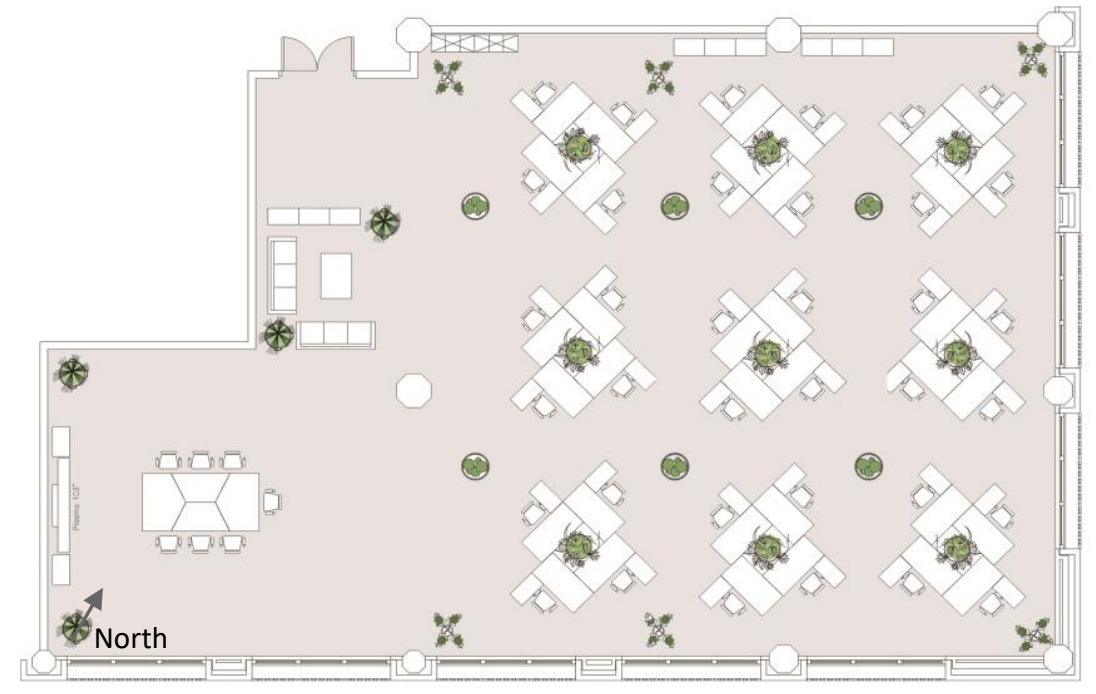


Figure (5) the first year studio after improvements
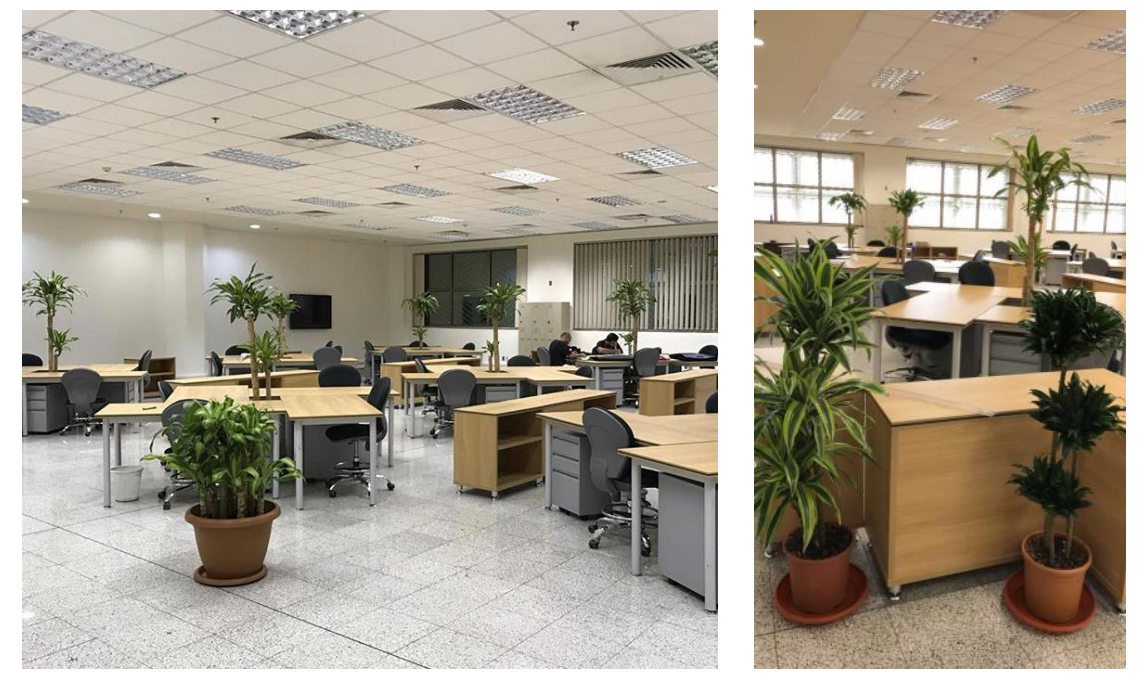

\subsection{Sample Size}

There were 45 students in their first year studying in the Landscape Architecture Department, who were invited to become participants for this study. Twenty-one students expressed an interest in participating in this investigation and form the sample size of this research. The others were excluded from this study. The behaviour of students was examined with input from the teachers (the researcher).

As mentioned before, the researcher began observations during the first term (2017), when no changes had been made to the layout of the studio. Blood pressure and heartbeat rate of the participants were then recorded during the first term by the researcher, who presents the result to a specialist doctor to read it and to help and assist the researcher create the analysis sheet of these readings. After the changing of the classroom, the blood pressure and heartbeat rate of the participants were recorded for three consecutive months. The readings were given to the same doctor who was aware of the purpose of this research to identify the differences, if any between the previous readings and the new readings. These participants were also asked to share their opinions with the researcher regarding the changes that had been made into the studio. These questions aimed to identify the student's attentional capacity, emotional, cognitive, and social wellbeing, and their opinion of the studio before and after the changes.

\section{FINDINGS}

This investigation has analysed how participants involved in learning activities in the studio are influenced by the introduction of plants into the classroom environment. When compared to countries in Europe and other Western countries, the natural environment of Saudi Arabia is not defined as green, but has a desert environment. However, these results indicate that plants have a positive influence on the mental and physical health of students. The systolic pressure (SYS), diastolic pressure (DIA) and pulse rate (Pulse) of all participants 
were measured before and after the introduction of plants into the green classroom learning environment. After the introduction of plants, participants were monitored for 3 consecutive months to record their health conditions. The results of these measurements suggested that the green classroom environment in the second term had a direct influence on improving the health, behaviour, and productivity of these participants.

These results also showed that there was a significant improvement in the systolic pressure of participants after a period of one month when they began studying in the green classroom environment (sig.=0.017). The average systolic pressure of participants at the end of third month was 124.86 (Table 2).

Table (2) Systolic pressure of participants before and after introduction of green plants

Mean Std. Deviation Std. Error Mean Sig.

$\begin{array}{lcrrr}\text { SYS } & 147.76 & 16.953 & 3.699 & - \\ \text { SYS after } 1^{\text {st }} & 126.19 & 8.328 & 1.817 & 0.017 \\ \begin{array}{l}\text { Month } \\ \text { SYS after 2 }\end{array}{ }^{\text {nd }} & 121.29 & 6.174 & 1.347 & 0.215 \\ \begin{array}{l}\text { Month } \\ \text { SYS after } 3^{\text {rd }}\end{array} & 124.86 & 8.569 & 1.870 & 0.920 \\ \text { Month } & & & & \end{array}$

The mean diastolic pressure of participants in the first month was 73.81, and at the end of the third month the average diastolic pressure was 73.05. At the end of the first month in the green classroom, there was a significant decrease in diastolic pressure with a mean value of 72.10 (sig. $=0.001$ ) (Table 3 ).

Table (3) Diastolic pressure of participants before and after introduction of green plants

Mean Std. Deviation Std. Error Sig.

\section{Mean}

\begin{tabular}{llllr} 
DIA & 73.81 & 8.524 & 1.860 & - \\
DIA after $1^{\text {st }}$ & 72.10 & 6.855 & 1.496 & 0.001 \\
$\begin{array}{l}\text { Month } \\
\text { DIA after 2 }\end{array}$ & & & & 0.749 \\
$\begin{array}{l}\text { Month } \\
\text { DIA after } 3^{\text {rd }}\end{array}$ & 71.33 & 2.972 & 0.649 & \\
Month & 73.05 & 6.265 & 1.367 & 0.722 \\
\hline
\end{tabular}

The normal pulse rate of a healthy individual is 72 beats per minute. The average pulse rate of participants before the introduction of plants was 72.33. At the end of the third month after the introduction of plants, the mean pulse rate of participants was calculated to be 72.29 (sig. $=0.896$ ) (Table 4). 
Table (4) Pulse rate of participants before and after introduction of green plants

Mean Std. Deviation Std. Error Sig.

Mean

\begin{tabular}{lcccr} 
Pulse & 72.33 & 9.886 & 2.157 & - \\
$\begin{array}{l}\text { Pulse after } 1^{\text {st }} \\
\text { Month }\end{array}$ & 72.86 & 8.284 & 1.808 & 0.462 \\
$\begin{array}{l}\text { Pulse after } 2^{\text {nd }} \\
\text { Month }\end{array}$ & 74.62 & 5.472 & 1.194 & 0.596 \\
$\begin{array}{l}\text { Pulse after } 3^{\text {rd }} \\
\text { Month }\end{array}$ & 72.29 & 6.672 & 1.456 & 0.896 \\
\hline
\end{tabular}

Table 5 shows observations gathered by the researcher of participants before and after the introduction of plants, which clearly indicate that the change of classroom learning environment had a positive influence on participants' behaviour.

Table (5) Observations gathered before and after changing the classroom design

\begin{tabular}{|c|c|}
\hline First term observations & Second term observations \\
\hline $\begin{array}{l}58 \% \text { of participants came late for the class, } \\
\text { including those not participating in the } \\
\text { research (class activities begin at } 10.00 \\
\text { twice per week). }\end{array}$ & $\begin{array}{l}\text { The number of students who came late for } \\
\text { the class decreased to } 21 \% \text { (class activities } \\
\text { started at } 10.00 \text { three times per week). } \\
\text { Some participants started to come early to } \\
\text { the studio to finish their homework or to } \\
\text { prepare their drawings for the class. }\end{array}$ \\
\hline $\begin{array}{l}74 \% \text { of participants asked for a break and } \\
39 \% \text { made excuses to leave the class to } \\
\text { drink coffee or to smoke. Some participants } \\
\text { left for no reason. }\end{array}$ & $\begin{array}{l}17 \% \text { of participants asked for a break and } \\
\text { those who wanted to leave to drink coffee } \\
\text { or to smoke decreased to } 12 \% \text {. }\end{array}$ \\
\hline $\begin{array}{l}\text { The class ends around } 16.00 \text {, but most } \\
\text { participants stopped working after the } \\
\text { break that starts at 12:30 and ends } 13: 30 \\
\text { (participants are not productive after the } \\
\text { break). }\end{array}$ & $\begin{array}{l}\text { This class is divided into three days, so it } \\
\text { ends at } 14.00 \text {, but it was surprising that } \\
\text { participants kept working even after } 14.00 \text {, } \\
\text { and often ignored the official end of class. } \\
\text { Some participants preferred to stay in the } \\
\text { studio to complete their classwork or to } \\
\text { start their homework for the next class. }\end{array}$ \\
\hline $\begin{array}{l}\text { The average number of absent participants } \\
\text { is high }\end{array}$ & $\begin{array}{l}\text { The average number of absent participants } \\
\text { has decreased. }\end{array}$ \\
\hline Participants appear bored and unfocused & $\begin{array}{l}\text { Participants appear happy and seem to } \\
\text { enjoy the class activities, and spend more } \\
\text { time in the classroom. }\end{array}$ \\
\hline
\end{tabular}




\section{DISCUSSION}

A study conducted by Tanner (2009) revealed that classroom learning environments have a strong influence on the behaviour and learning of students. The cognitive and social skills of students are positively correlated with plants in the studying environment (Yacan, 2014). According to Huang et al. (2015), students' attainment is enhanced and their health is improved when they experience green classrooms, because these positive effects tend to create an environment that is healthy. Another important and significant factor of green classrooms is that they are a clear technique that can be adopted to ensure greater awareness of environmental issues. Zhongguo (2004) argued that green classrooms construct a perception of civilisation from a spiritual context, and that students are exposed to educational activities that are focused on quality. This present study revealed that participants showed greater interest in learning activities after the introduction of plants within the classroom.

Over recent years, professionals studying design and architecture have been increasingly integrating green spaces into construction projects. The academics have recognized that students' productivity and personal health are enhanced by introducing green plants into learning environments. Green classrooms appear to link environmental concerns and solutions with building designs, so that optimal design improves students' learning opportunities. Students appear to perform exceptionally well when they are provided with green classrooms along with natural light. Gelfand (2010) suggested that learning environments should be designed with the incorporation of green plants, as this represented effective investment for teaching and learning. Learning environments described as healthy are provided by green classrooms, as these enable students to access indoor quality air, acoustics, natural lighting, and comfort (Huang et al., 2015). Other benefits reported by Huang et al. (2015) include students demonstrating better attendance rates for lessons and higher levels of attainment when learning in green classrooms. Therefore, green classrooms appear to have a positive impact on students' motivation and absenteeism, as well as enhanced job satisfaction for teachers.

Design elements adopted for use in green classrooms contribute to improve the quality of classroom resources, which is also shown to reduce levels of stress for students. This improvement in students' performance appears to be associated with the introduction of green plants into classrooms, because the moods of teachers and students are associated positively with the connections made by them between green plants and nature. A study conducted by Han (2009) revealed that academic success and behaviour of students were improved after the introduction of plants within the classroom. Levels of satisfaction reported by students were also shown to improve. According to Daly et al. (2010), the plastic elements of tables and chairs normally found in classrooms emit into the air organic compounds that are volatile, but the concentration of these is decreased when plants are introduced into classrooms, and carbon dioxide levels are also decreased as a result of these 
green plants. When there is an increase in concentrations of carbon dioxide in classrooms, it results in drowsiness and loss of concentration, which affects the health of students and teachers.

These results revealed that there is a positive impact of green plants on the academic success and health of participants. Most participants reacted positively when they saw green plants being placed within their classroom setting, which suggests that green classrooms contribute to participants' well-being and health. The use of green plants represents many benefits for improved learning and behaviour. It has also been shown that green classrooms improve environmental attitudes of students towards using elements of nature. The positive attitudes of students reported in this study regarding the introduction of plants into classrooms, supported a recommendation that plants should become a standard installation for all classrooms. However, the findings are based on a very small sample size, and further research into green classrooms should involve researchers studying different cities and regions with a larger sample population. This would further validate these findings by reducing the probability error.

\section{CONCLUSION}

This study aims to examine the effect of the classroom design in the student behaviour. It been noticed that, taking into consideration the design of the classroom and the green elements within the class support the students cognitive function and to make the classroom an attractive spaces for learning in compare with the typical classroom that lack of design. This is a significant finding for university classroom especially in a design school where students spent the majority of their time in these studios to come up with creative design projects.

\section{ACKNOWLEDGEMENT}

The author is very thankful to all the associated personnel in any reference that contributed in/for the purpose of this research including the landscape architecture department students and staff members. In addition, the research wants to thank Doctor Najya Jan Abdulkhalq for supporting him to understand the medical factors related to blood pressure and heart beats.

\section{REFERENCES}

Bagot, K. L., Allen, F. C. L., \& Toukhsati, S. (2015). Perceived restorativeness of children's school playground environments: Nature, playground features and play period experiences. Journal of Environmental Psychology, 41, 1-9. doi:10.1016/j.jenvp.2014.11.005

Daly, J., Burchett, M., \& Torpy, F. (2010). Plants in the classroom can improve student performance. National Interior Plantscape Association.

Demir, A., \& Konan, A. P. D. N. (2013). Impact of daylighting on student and teacher performance. Journal of Educational and Instructional Studies in the World, 3, 7. 
Gelfand, L. (2010). Sustainable school architecture: Design for elementary and secondary schools. John Wiley \& Sons.

Han, K. T. (2009). Influence of limitedly visible leafy indoor plants on the psychology, behavior, and health of students at a junior high school in Taiwan. Environment and Behavior, 41, 658-692. Doi: 10.1177/0013916508314476

Heschong, L., Wright, R. L., \& Okura, S. (2002). Daylighting impacts on human performance in school. Journal of the Illuminating Engineering Society, 31, 101-114. Doi: 10.1080/00994480.2002.10748396

Huang, K. T., Huang, W. P., Lin, T. P., \& Hwang, R. L. (2015). Implementation of green building specification credits for better thermal conditions in naturally ventilated school buildings. Building and Environment, 86, 141-150. Doi: 10.1016/j.buildenv.2015.01.006

Kuller, R., Lindsten, C. "Health and Behavior of Children in Classrooms with and

Martensson, F., Boldemann, C., Soderstrom, M., Blennow, M., Englund, J. E., \& Grahn, P. (2009). Outdoor environmental assessment of attention promoting settings for preschool children. Health \& place, 15, 1149-1157. Doi: 10.1016/j.healthplace.2009.07.002

Pulay, A. S. (2010). Awareness of daylighting on student learning in an educational facility.

Tanner, C. K. (2009). Effects of school design on student outcomes. Journal of Educational Administration, 47, 381-399. Doi: 10.1108/09578230910955809

Wang, N., \& Boubekri, M. (2010). Investigation of declared seating preference and measured cognitive performance in a sunlit room. Journal of environmental Psychology, 30, 226-238. Doi: 10.1016/j.jenvp.2009.12.001

without Windows." Journal of Environmental Psychology 12, no:3 1992: 305- 317.

Van den Berg, A. E., \& Van den Berg, C. (2011). A comparison of children with ADHD in a natural and built setting. Child: Care, Health and Development, 37, 430-439. doi:10.1111/j.13652214.2010.01172.x

Van den Berg, A. E., \& Van den Berg, M. M. H. E. (2014). Health benefits of plants and green space: Establishing the evidence base. Acta Horticulturae. 1093, 19- 30. doi:10.17660/ActaHortic.2015.1093.1

Yacan, S. (2014). Impacts of Daylighting on Preschool Students' Social and Cognitive Skills.

Zhongguo, T. (2004). Establishing green schools and enhancing teachers and students' environmental awareness. Chinese Education \& Society, 37, 94-96. 